\title{
Flow and rent-based opportunity costs of water ecosystem service provision in a complex farming system
}

\author{
Olivia R. Rendon ${ }^{1}$, Martin Dallimer $^{1}{ }^{\text {and Jouni Paavola }}{ }^{1}$
}

\begin{abstract}
Unsustainable land uses present many challenges for securing ecosystem service provision. It is also difficult to estimate the cost of a transition to more sustainable land-management practices for individual landholders. The main cost to landholders is the opportunity costs, the income foregone when changing land use for continued or enhanced ecosystem service provision. Thus accurate estimation of opportunity costs and understanding their distribution are crucial starting points for determining the economic viability and design of any payment for ecosystem services (PES) scheme. We compare two opportunity cost approaches and examine the distribution of these costs for improving drinking water quality in a complex farming system in a Honduran forest catchment. Data for both approaches was collected through a survey applied to upstream catchment landholders. Our results indicate that the direct flow approach and the proxy rent approach provide comparable and consistent opportunity cost estimates. The mean net flow return $\mathrm{ha}^{-1}$ was US $\$ 1410$, but this estimate was skewed, mainly by exceptionally high coffee returns and negative returns of land uses making a loss. This estimate would imply spending over US\$2 million per annum for water conservation, but a revised estimate comes to US $\$ 257,057$ per annum. Opportunity costs were found to vary according to differences in land use and landholder characteristics. High value cash crops upholding the local economy, such as coffee, entail much higher opportunity costs than for example cattle grazing. These results suggest that discriminate PES payments, that vary according to opportunity costs and thus discriminate between land uses and landholders, are essential. Water quality at our case study site could be managed sustainably by a scheme focusing on highimpact land uses with lower opportunity costs and closer to water sources.
\end{abstract}

Key Words: coffee; Honduras; land use; opportunity costs, payment distribution; payment for ecosystem services; tropical forest; water quality

\section{INTRODUCTION}

Unsustainable land-use practices pose many challenges for managing land for ecosystem service provision (Wünscher et al. 2011). In particular, securing safe drinking water is a major issue in developing countries because of a complex array of threats on both the demand and supply side (Rangel Soares et al. 2002, Jouravlev 2004, Trevett et al. 2004, UNICEF and WHO, 2012). In rural areas, water pollution typically originates from unsustainable land uses, poor sanitation, and other factors, involving numerous and dispersed land users (Olmstead 2010, Smith and Porter 2010, Smith et al. 2012). Thus, it is often necessary to restrict or change current land use to secure the provision of water for beneficiaries. There is also a need for efficient governance structures and incentive mechanisms to transition to more sustainable land-management practices.

Payments for ecosystem services (PES) schemes are one way to finance and incentivize improved water provision in developing countries. These schemes transfer financial resources from beneficiaries to those providing the service to cover the costs of provision. There are several debated issues surrounding PES scheme design and implementation that need further research. One of them is how to accurately estimate the costs of provision with the best approach (Wunder 2005, Wünscher et al. 2008). Second, deciding what the aim(s) of the scheme will be, by either targeting environmental benefits, the reduction of the risk of ecosystem services loss, or simply landholders' costs of participation, including opportunity costs (Wunder 2005, Asquith et al. 2008, Bruijnzeel and Noordwijk 2008, Plumb et al. 2012). A third debated issue is how to determine who gets paid what in PES schemes (Wunder 2005, Wünscher et al. 2008). Both uniform payments (all participants paid the same) and discriminating payments (participants paid differently according to provision or another factor) have been used (Claassen et al. 2008, Pagiola 2008, Chen et al. 2010). Targeting approaches can render PES schemes a poverty alleviation tool or a means to make the well-to-do better off (Pagiola and Platais 2002, Rosa et al. 2003, Pagiola et al. 2005).

It is difficult to determine precise and fair compensation to service providers because of heterogeneous land costs, multiple stakeholders, methodological limitations, and inequitable distribution of project outcomes (Corbera et al. 2007a, Adams et al. 2010, Dong et al. 2011, Bryan 2013, FFI 2014). The main costs borne by landholders are opportunity costs; the income foregone by a landholder when changing land use to provide continued or enhanced ecosystem services (e.g., Sinden 2004, Naidoo and Adamowicz 2006). Opportunity costs are based on scarcity and exclusiveness because one course of action prevents another one from happening (Sinden, 2004, Naidoo and Adamowicz 2006, Pirard 2008). Estimating opportunity costs accurately and understanding their distribution based on land and landholder attributes is a crucial starting point to determine the economic viability and design of PES schemes (Pagiola and Bosquet 2009, Plumb et al. 2012).

The opportunity cost literature uses approaches like net returns from land uses, proxies obtained from land attributes, and land prices for estimating opportunity costs, and more recently screening contracts and procurement auctions have also been used 
(e.g., Borrego and Skutsch 2014, Chomitz et al. 2005, Jack et al. 2009, Naidoo and Adamowicz 2006, Wünscher et al. 2011). These methods have been used to calculate the cost of conservation, to assess trade-offs in land allocation, and to design PES schemes (Pagiola and Bosquet 2009). However, all these methods have weaknesses. Screening contracts require detailed knowledge about the distribution of landowner types and sophisticated calculations by conservation practitioners (Wünscher et al. 2011). Procurement auctions are complex to design and require a large pool of bidders (Ferraro 2008, Tóth et al. 2010). The accuracy of land attribute information will only be as good as the strength of the correlations between the attributes and landholder types (Naidoo and Adamowicz 2006). Land-use net returns, or the flow approach, has many assumptions, requires costly and timeconsuming data collection, must account for short-term variability of returns, and needs in depth knowledge of the local context (Plumb et al. 2012). The rent approach in turn requires existing and well-operating land markets (Cattaneo 2002, Ferraro 2004, Grieg-Gran 2008).

Considerable challenges exist for understanding the relationships between different opportunity cost methods and for identifying a reliable, accurate, and cost-effective method to determine the opportunity costs of conservation (Wünscher et al. 2011). Some studies have used two or more approaches to obtain more robust opportunity cost estimates. For example, Corbera et al. (2007b) estimated opportunity costs through net farm returns, valuation of the providers' willingness to accept (WTA) a price for PES, and the expected land rent in three Central American countries. They found that different methods and assumptions yield considerably different opportunity cost estimates. Wünscher (2008) compared the use of hypothetical annual land rents, modeled regressions, and farm net returns to determine opportunity costs in Costa Rica. They recommend annual land rents and modeled regressions approaches for practical application in conservation programs. However, they also identified a need for further research into opportunity cost estimation, particularly into the flow approach used to determine farm net returns because it did not always perform well.

Traditional approaches to opportunity cost estimation also tend to assume that opportunity costs can be estimated from proxies, such as land attributes (Hunt 2010, Fisher et al. 2011 $a, b$ ) and land market prices (Chomitz et al. 2005). This is usually an oversimplification because opportunity costs are likely to vary spatially (e.g., with land use, accessibility, distance to water, plot size, altitude) and according to socio-demographics of landholders (e.g., age, gender, schooling, household size). In particular, household attributes of landholders have only rarely been included in opportunity costs estimation, and we need to understand their effect on PES scheme participation and effectiveness (for exceptions see Naidoo et al. 2006, Siikamaki and Layton 2007). Quantifying the impact of landholder and land attributes is an essential first step in developing a cost effective PES scheme, especially in areas without robust land markets because opportunity costs in provider groups, and the ecosystem services provided, are often heterogeneous (Tallis and Polasky 2009, Adams et al. 2010, Badola et al. 2010, Chen et al. 2010).

This research aims to apply and compare two different opportunity cost approaches, adding support to their usage. It also aims to understand the extent to which landholder and land attributes explain opportunity cost heterogeneity. We do this by estimating the opportunity costs of water provision in a Honduran forest catchment in which multiple land uses coexist and land markets are ambiguous. We use the flow approach, the most widely used direct method that does not always generate consistent results so needs further research; and the rent approach, a proxy method, which is the most cost-effective approach but which is said to require a well-operating land market. We demonstrate below that the rent and flow approaches to estimating opportunity costs provide broadly comparable results, which are useful for designing water conservation initiatives, including PES schemes.

\section{METHODOLOGY}

\section{Study site}

This research was conducted in the west of Honduras (area $112,492 \mathrm{~km}^{2}$ ), a country in Central America with a population of over 8 million. More than half of the people live in rural areas and two thirds live below the poverty line (FAO 2010, INE 2014). Honduras has abundant water resources but uses less than $10 \%$ of its hydrological potential (GWP-Centroamerica 2011). Thus, water availability is not an issue, but accessibility and quality are. There is a long tradition of centralized command-and-control style conservation based on protected areas. However, limited political will and capacity to implement conservation policy means that most protected areas are "paper parks" (Martin and Blackburn 2009, Agulla Menoni 2012). Honduras' economy is highly dependent on natural resources, agriculture, and forestry (Jansen et al. 2006, Gareau 2007, Larson et al. 2007). This means that there is a substantial challenge in managing land for both conservation and livelihoods. Local livelihoods, which are often carried out unsustainably, and conservation objectives are thus often in conflict (Rivera et al. 2013, Ericksen et al. 2002, Southworth et al. 2004).

The Güisayote Biological Reserve (Fig. 1) was created in 1987 as one of 37 rainforest areas that provide key hydrological services, i.e., water for domestic and industrial use (ICF 1987). A biological reserve is one of the strictest protected area management categories:

an untouchable area that contains ecosystems, aspects or flora and fauna of scientific value. Its main function is to protect, conserve and maintain unaltered phenomena or natural processes, for studies and scientific research

(SRNA 1997).

This means that all agricultural and extractive activities are prohibited in the core zone and restricted in the buffer zone. The reserve has been managed by the NGO Asociación Ecológica San Marcos de Ocotepeque (AESMO) since 2003. The reserve is located between 1140 and $2310 \mathrm{~m}$ above sea level, with an average temperature between $18-22{ }^{\circ} \mathrm{C}$. Annual precipitation is high $(1150-1300 \mathrm{~mm})$ with a rainy season from May to October and a dry season from November to April. The highest parts of the reserve have rain throughout the year with a relative humidity of 82 to $93 \%$ and an abundance of both permanent and temporal streams (AESMO 2010). 
Fig. 1. Güisayote Biological Reserve showing the study site (solid black outline), rivers, water sources, and roads in the reserve. Inset shows location of the reserve in Honduras.

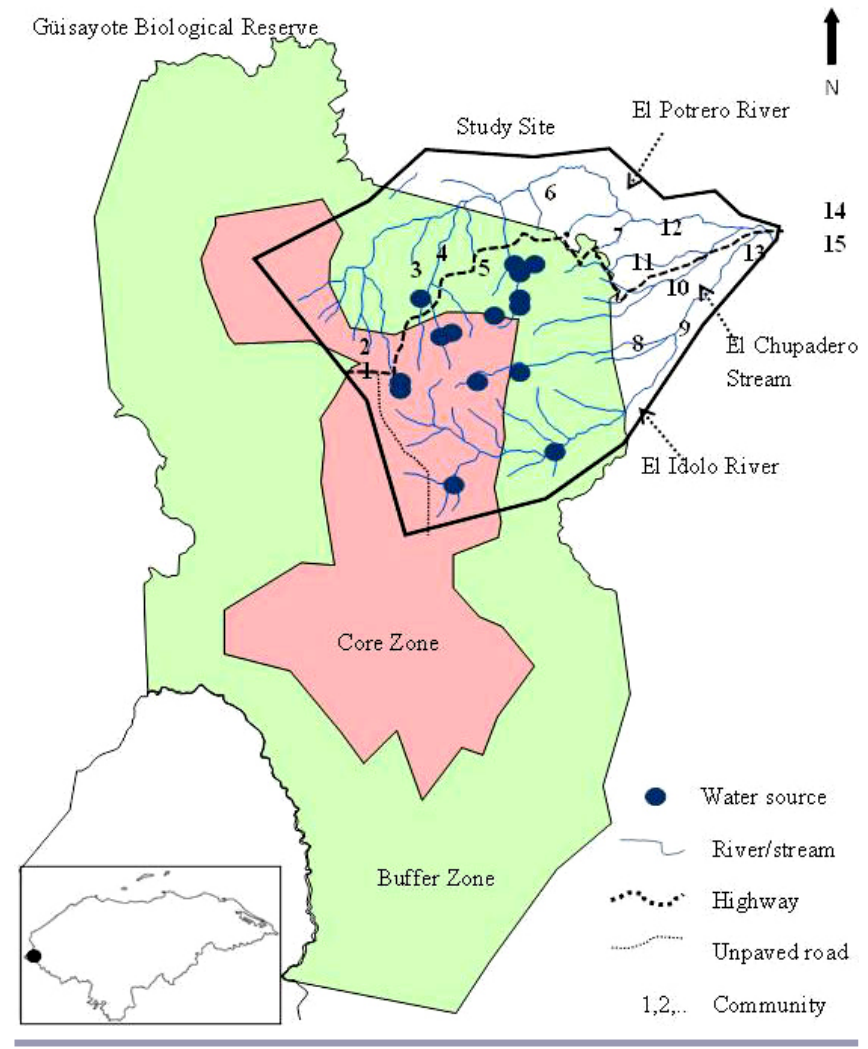

Our research site encompasses 4793 ha, with an upstream catchment area of 2086.7 ha (including 243.6 ha owned by AESMO, the municipality, and a community) of rugged topography with very steep slopes in the watershed formed by the Idolo, El Potrero, and El Chupadero rivers in the reserve (Fig. 1). The site includes the core and buffer zone of the reserve, and unprotected land. The watershed provides drinking water to 15 communities with an estimated population of 7725 (ESNACIFOR and USAID, 2002). The watershed is threatened by varied and complex problems, such as high levels of deforestation with only $30-68 \%$ of the reserve having forest cover (ESNACIFOR and USAID 2002), forest degradation, and agriculture activities for subsistence and commerce carried out by upstream landholders (with associated open-air defecation). Likewise, local inhabitants make (illicit) use of public and private forests for poles, medicine, firewood, shade, and cattle grazing (AESMO 2010). These activities all contribute to the contamination of water sources, by excessive nutrients, agrochemicals, bacteria, and fecal coliforms (Regional Public Health Officer, 25 February 2011, unpublished data). Asociacion Ecologica San Marcos de Ocotepeque(AESMO) and the German corporation GIZ are currently studying the possibility of developing a water PES scheme at this site.

Our research considers a land set-aside payment for ecosystem services (PES) scheme for water quality provision. Land set-aside involves landholders halting all land use for a contracted period, including monitoring unused land, allowing natural regeneration, and receiving a payment in return. It is important to note that aiming to increase water quality and quantity, more so the latter, through the expansion of forest cover is highly debated and often dependent on site-specific factors, such as forest cover, rainfall patterns, and erosion (Bruijnzeel 2004, Aylward 2005, Scott et al. 2005, Kosoy et al. 2007). Although land set-aside is not the only PES option, it is being considered by AESMO, therefore we examined it as a way to manage a biological reserve subject to strict conservation regulations and to ensure water provision in the context of multiple nonpoint pollution sources, including hard-to-control open-air defecation that accompanies productive land uses. Experience with past and current conservation efforts, such as patrolling, fencing, and legislation indicate that it is next to impossible to secure provision of clean water with anything less than land set-aside. It could also be effective not only for improving water quality, but also for other ecosystem services, such as flow regulation and habitat preservation (Postel and Thompson 2005).

\section{Landholder and land characteristics}

Upstream private landholders (i.e., landowners and renters) have dispersed plots, with (self-reported) secure land tenure used mainly for coffee, vegetables, and cattle ranching. Coffee is mainly grown at lower heights for national and international markets, and it is cultivated with few agrochemicals and without irrigation. Vegetables (e.g., potato, cabbage, and carrot) are grown at higher altitudes for national markets with ample use of agrochemicals and summer irrigation. Cattle ranching takes place across the research site for subsistence and local markets (milk and cheese, seldom for meat). Some maize and beans are also grown for subsistence. Coffee and vegetable growing are the most profitable land uses but they are also affected by volatile market prices (e.g., Charveriat 2001, Mohan 2007), which influence opportunity cost estimates. Coffee growers belong to one of several producer associations and cooperatives.

\section{Opportunity cost estimation}

Data were collected between 21 February and 29 October 2011. Several initial visits to the watershed and informal interviews with farmers helped to map land ownership because no registry for cultivated land existed. A total of 95 upstream landholders were identified in the catchment and attempts were made to contact all of them to take part in the research. Landholder trust was gained by living and working in the area for other aspects of the research for five months before the survey took place. During this time, focus groups were conducted with farmers, municipality meetings where farmers were present were attended, and formal and informal conversations were had with farmers. The time also involved numerous visits accompanied by staff of the local NGO and mapping of farms and land use with farmers themselves.

The use of two opportunity cost methods formed a triangulation process because four values were obtained: opportunity costs and three land values. Landholders were interviewed starting with those next to the community water sources (i.e., mountain springs with infrastructure providing water to each community) and then working outward. Two thirds (62/95) of landholders completed the survey for the flow approach and 39 completed 
the would rent values, 74 the would sell values, and 56 the actual land-purchase values, based on (un-) willingness to provide land values. Only 10 landholders refused to participate and the remaining 23 landholders could not be contacted after 3 attempts. The majority of landholders $(84 \%)$ were residents in the waterusing communities, making them beneficiaries of the service as well as providers (referred to as dual landholders throughout the rest of the paper).

Our survey was designed to estimate the cost of taking land out of production through the flow and rent opportunity costs approaches and is available in Spanish from the lead author upon request. The survey was administered face-to-face with the landowner or the tenant, whoever carried out the farming activities. Questions about landholder and land characteristics, land values, inputs (e.g., fertilizer, vaccine) and outputs (e.g., crop yield) of all productive land uses in 2010-2011 were asked. Labor wages were found to be quite homogeneous across the research site. Respondents were also asked to draw maps of their plots and highlight their main features, such as land-use patterns, neighbors, roads, watercourses, and infrastructure. No reference was made in the survey to the legality of forest resource use to avoid influencing responses; though some respondents may have been aware of the legal implications of extracting forest resources in a reserve. Whenever self-consumption yields were reported, they were ascribed a market value stated by the respondent or the average for all landholders. All values were obtained in Honduran Lempiras for the local unit of land area manzana (equal to 0.7 ha), and converted to US dollars $\mathrm{ha}^{-1}$ at an exchange rate of US\$ 1 to Lps. 18.8951 (2011 values).

\section{Flow opportunity cost approach}

The flow approach estimates net returns from land use at the local level. The opportunity costs were estimated per landholder and per hectare for one year by subtracting total costs from total revenue for each land use, multiplied by the area used, to obtain net return ha ${ }^{-1}$. Following Fisher et al. (2011b) the total opportunity costs were obtained as follows:

$$
V=\left[\sum_{i}^{l} A_{i} y_{i} P_{i}\right]-C_{i}
$$

where $V$ is the net agricultural returns of the average hectare in US\$, summed across all land uses; $A_{i}$ is the plot size in hectares with land use $i ; y_{i}$ is the yield of land use $i ; P_{i}$ is the price of land use $i$ in US\$ per yield unit; and $C_{x}$ is the cost of inputs including labor, tools, and agricultural materials.

Several assumptions were made to estimate the opportunity costs using the flow approach. First, personal and family labor was valued at $50 \%$ of the local laborers' ("jornal") wage. This was considered justifiable because there are few off-farm income earning opportunities within reasonable distance for the landholders (for further discussion on the value of family labor see Wünscher 2008, Wünscher et al. 2011). Second, negative net returns from lost crops were included in the initial analysis to obtain insight into local heterogeneity of opportunity costs. However, agricultural returns vary from year to year. Thus, in the final analysis, positive values and positive values excluding coffee were estimated. Because historical opportunity costs were unavailable, these positive estimates were assumed to represent the appropriate long-term balanced value required for further analyses. The negative values from low prices in cattle and crop markets and the extremely high positive values from coffee being at its highest for a decade were removed, to make the flow opportunity costs comparable to the more stable land rent values.

The determinants of opportunity costs were analyzed at landholder and plot levels. The variables that were tested for landholder and plot opportunity costs were based on the literature and data availability (e.g., Grieg-Gran 2008, Wünscher et al. 2011, Curran et al. 2016; Table 1). Continuous variables were tested through Spearman's $\rho$ correlations and categorical variables through Mann-Whitney U tests. The probability of presence of each productive land use was then tested using binary logistic regressions. The tested independent variables include elevation, time to main road, access to land throughout the year, slope, and time to water.

Table 1. Independent variables that were tested for association with two levels of opportunity costs, per landholder and per land plot, and their expected sign.

\begin{tabular}{lclc}
\hline \hline Landholder variables & $\begin{array}{c}\text { Expected } \\
\text { sign }\end{array}$ & Land variables & $\begin{array}{c}\text { Expected } \\
\text { sign }\end{array}$ \\
\hline Age in years & + & Plot size & + \\
Years of education & + & Time to road & - \\
Family size & + & Time to water & - \\
Female & $?$ & Time to house & - \\
Proportion of & + & Altitude & $?$ \\
household income & & & \\
coming from farmer & & & + \\
Only agriculture income & + & Accessibility & + \\
Number of plots used & + & Number of plots & + \\
& & used & - \\
Land owned & + & Years owned & + \\
Number of land uses & + & Presence of forest & + \\
Presence of coffee & + & Presence of coffee & - \\
Presence of cattle & - & Presence of cattle & + \\
Presence of crops & + & Presence of crops & + \\
\hline
\end{tabular}

Rent opportunity cost approach

To estimate rent opportunity costs, respondents were asked to state three different economic land values: "would rent" value, "would sell" value, and "purchase price." These three values were elicited as the best option for the study site because the local land market is informal and no records exist for land transactions. It was assumed that the annual "would rent" price of a plot of agricultural land is equal to its annual net revenue flow, whereas the "would sell" and "purchase price" of a plot of land are equal to the discounted flow of net revenue that the parcel is expected to generate into the future (Weersink et al. 1999, Cavailhes and Wavresky 2003, Goodwin et al. 2003). "Would rent" and "purchase prices" were divided by plot size to obtain per hectare rent value. The land "purchase prices" included transactions carried out between 1961 and 2011, so they were adjusted for inflation by multiplying by the consumer price index (CPI) of the year of purchase and divided by the $2011 \mathrm{CPI}$ (obtained from the Central Bank of Honduras). Thus, the formula to determine 2011 "purchase values" was:

Land Purchase value 2011 (LPV2011)

$$
=\text { Purchase price } *\left(\frac{C P I \text { of } \text { Year }_{x}}{C P I_{2011}}\right)
$$


"Purchase values" and the "would sell" prices were multiplied by $5.25 \%$, the average general interest rate for 2011 in Honduras (BCH 2011), to obtain land-market value, as a capitalization rate is not available for Honduras. Land-market value is the landrental value, minus land taxes, divided by a capitalization rate. The capitalization rate is a market determined rate of return that would attract individuals to invest in the use of land, considering all of the risks and benefits that could be realized (Gwartney 1999). Tax reporting was highly inconsistent by respondents, so it was excluded from these estimations. The use of one off interest rate for all plots affects absolute but not relative estimated land values, so does not affect our findings. We acknowledge that there are many other factors, besides productivity, which can influence how much landowners are willing to rent or sell their land for, including changes in markets, economic or environmental policy, and human preferences or culture (Naidoo and Adamowicz 2006).

\section{The flow and rent approaches}

The flow approach is a direct opportunity cost estimation that provides detailed insight into local heterogeneity, market dynamics, and the influence of individual land-user groups. The rent approach is a proxy estimation of opportunity costs that provides a less detailed, but more stable and longer-term view excluding the effect of extreme and variable market dynamics. Specifically, for the rent approach: the "would rent" values are the equivalent of a stated willingness-to-accept (WTA) for settingaside land without losing ownership or potential nonuse benefits. The "would sell" values are the price of forfeiting all future streams of income and nonmarket benefits from the land. The "actual purchase price" values are actual market values (although land degradation and other factors may have reduced its value since purchase). The two approaches were compared to assess the trade-offs between them and their effectiveness at estimating accurate opportunity costs. For the flow estimates to be comparable to the rent estimates, the negative and extreme values of the former, indicative of variable market dynamics, were removed. The use of both approaches adds robustness to estimates and consequently to the claims based on those estimates.

\section{Opportunity cost heterogeneity}

To understand the factors that determined high and low opportunity costs, net returns were assessed using the flow approach per landholder and land use. A two-tailed Spearman's rho was used to correlate landholder net returns $\mathrm{ha}^{-1}$ with the number of plots used and the number of land uses. Mann Whitney $\mathrm{U}$ Tests were used to compare the landholder opportunity costs to gender and the presence of each land use (i.e., categorical independent variables). Finally, binary logistic regressions were carried out to assess the impact of five variables on the likelihood that respondents would report growing coffee, crops, and cattle.

\section{RESULTS}

\section{Landholder and land characteristics}

Respondents were mostly male $(89 \% ; n=62)$ with a mean age of $56(\mathrm{SD}=12.76)$. They had a mean of four years of schooling (SD $=4.93)$ and five family members $(\mathrm{SD}=2.74)$. Farmers carried out a mean of 1.5 productive activities $(\mathrm{SD}=0.95)$, with some being specialists (coffee growing and cattle ranching are taught from father to son from an early age) and others being constrained by land characteristics or lack of agronomic training. The household income came from few sources $(2.53, \mathrm{SD}=1.71)$ and generally the landholder was the main income earner $(75 \%$, SD $=34.21)$. Landholders owned one plot on average $(\mathrm{SD}=0.58)$ and plots had been owned for many years $(18, \mathrm{SD}=11.32$; see Appendix 1).

The amount of land owned by respondents varied widely (mean $=15$ ha, range 0.7-126 ha; Table 2). Plot size had a similar range, 0.18 ha to 126 ha, to total land owned, but a mean of 9 ha. Forest was the most common land cover and landholders reported a mean forest age of 32 years. Cattle ranching was the most common productive land use followed by coffee and crops. A small land area $(15 \%)$ was also dedicated to renting, loaning, and fallow.

Table 2. Land and land use distribution among opportunity cost survey respondents $(n=62)$.

\begin{tabular}{lcccccc}
\hline \hline Variable & Total ha $\left(\%^{\dagger}\right)$ & $\begin{array}{c}\text { Mean } \\
\text { ha }\end{array}$ & SE & SD & Range & $\begin{array}{c}\% \\
\text { Farmers }\end{array}$ \\
\hline Land/ & -- & 14.7 & 3.01 & 23.72 & $0.7-126$ & -- \\
farmer & & & & & & \\
Plot size & -- & 9.1 & 2.37 & 18.63 & $0.18-126$ & -- \\
Forest & $357.28(39)$ & 5.6 & 1.82 & 14.34 & $0-64.75$ & 42.7 \\
Cattle & $319.2^{\ddagger}(35)$ & 4.9 & 1.38 & 10.86 & $0-70$ & 38.5 \\
Coffee & $69.44(8)$ & 1.4 & 0.22 & 1.73 & $0-5.6$ & 29.4 \\
Rented & $54.6(6)$ & 0.7 & 0.85 & 6.67 & $0-52.5$ & 2.1 \\
Loaned & $41.86(5)$ & 0.7 & 0.33 & 2.6 & $0-18.2$ & 13.3 \\
Fallow & $39.7(4)$ & 0.7 & 0.21 & 1.62 & $0-8.58$ & 18.9 \\
Crops & $32.2(3)$ & 0.7 & 0.12 & 0.92 & $0-4.2$ & 25.2 \\
\hline
\end{tabular}

'Refers to net land use;

tThis area only includes land used for cattle ranching within the study site. Total area of land for cattle ranching includes land borrowed or rented outside the study site, which amounted to 595.88 ha;

$\$$ includes vegetables, maize, beans, improved grass, and sugar cane; 'Approximately 15 ha of vegetable land was used more than once in the year, and 5 ha of maize and beans were used more than once or overlapped with coffee.

\section{Opportunity cost estimation}

Flow opportunity cost

The mean net return $\mathrm{ha}^{-1}$ was US $\$ 1410$ and the median was US\$19 $\mathrm{ha}^{-1}$ (Table 3). These estimates were skewed by: (1) the high coffee returns due to an exceptionally good market price, (2) the negative returns of land uses making a loss, and (3) the unused forests. Although the negative values reflected real market dynamics, they introduced high variance into the data. Hence, two variations of the flow approach were estimated, "flow positive," which only includes positive values, and "flow positive-no coffee," which excludes coffee values. The flow and flow positive means of opportunity costs would imply spending over US\$2 million for water conservation annually. However, the flow and flow positive estimates are influenced by outlying opportunity costs and are unlikely to represent long-term costs. The flow positive-no coffee provided a substantially smaller, but more realistic estimate of the cost of water conservation at the study site of US\$257,057 per annum. 
Table 3. Net returns US\$ ha-1 with the flow and rent approaches. Flow estimates are per land use and include forest zeros; all rent values included once, no matter how many land uses per plot; mean, median, minimum, and maximum rounded to zero decimals to enhance clarity.

\begin{tabular}{lcccccc}
\hline \hline Values & $\mathrm{N}$ & Mean & Median & SE & SD & Range \\
\hline Flow & 186 & 1410 & 19 & 402.86 & 5494.21 & $-21,757-24,086$ \\
Flow positive & 139 & 2666 & 263 & 459.08 & 5412.46 & $0-24,086$ \\
Flow positive- & 113 & 1839 & 140 & 409.04 & 4348.16 & $0-24,086$ \\
no coffee & & & & & & \\
Would rent & 39 & 245 & 151 & 38.72 & 241.83 & $4-1134$ \\
Would sell & 74 & 546 & 397 & 58.82 & 506.02 & $15-2977$ \\
$\begin{array}{l}\text { Actual } \\
\text { purchase price }\end{array}$ & 56 & 425 & 160 & 92.97 & 695.74 & $1-2977$ \\
\hline
\end{tabular}

Figure 2 shows the spread of net returns ha ${ }^{-1}$ for each productive land use using the flow approach. Cattle ranching and forest show the least spread of data and central values because of low reported forest use, and cattle farmers reporting a bad year. Only 10 out of 52 forest plots were reported to be used in the study year. Coffee and vegetables show the widest spread of data and highest values because of the good year for both crops. However, both cattle and crops reported several negative values owing to low market prices. Furthermore, the median net return of coffee is two orders of magnitude greater than the next highest median, crops (US\$261). That is, coffee provides the highest returns and dominates the opportunity costs of water conservation.

Fig. 2. Net returns in US\$ ha-1 for each productive land use for 2010-2011. The dotted line represents zero; circles $=$ values beyond the extents of the second quartile; stars = extreme values beyond the first and third quartiles; bold lines = median; forest $\mathrm{N}=52$, mean $=$ US $\$ 35$, median $=0$; cattle $\mathrm{N}=48$, mean $=\mathrm{US} \$ 282$, median $=\mathrm{US} \$ 44 ; \operatorname{crops} \mathrm{N}=58$, mean $=\mathrm{US} \$ 1501$, median $=$ US $\$ 261 ;$, and coffee $\mathrm{N}=28$, mean $=$ US\$5710 and median $=$ US\$2248.

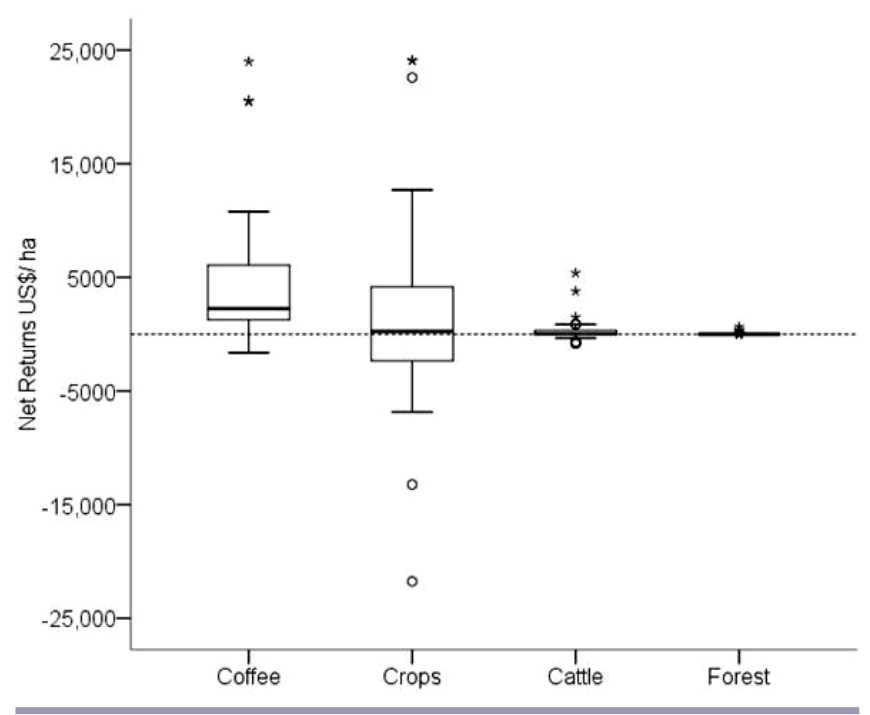

Rent opportunity cost

The 3 rent values were estimated on 39 "would rent" values, 74 "would sell" values and 56 actual land purchase values based on respondents (un)willingness to provide a value. The total mean "would rent" value ha ${ }^{-1}$ is US\$245, "would sell" is US\$546, and actual purchase price is US\$425 (Table 3). These values provide totals for the cost of water conservation of US\$278,308 for "would rent," US\$731,711 for “would sell," and US\$294,896 for purchase price.

\section{The flow and rent approaches}

The mean $\mathrm{ha}^{-1}$ value differs widely between the flow and rent estimates but these estimates are correlated (Table 4). Specifically, "flow positive" and "flow positive-no coffee" returns are correlated to the rent values, but the raw flow returns (i.e., those including negative returns and returns from coffee) are not. Although coefficients are low, the high levels of confidence $(95-99 \%)$ indicate a consistent response by landholders across the three rent values. The "flow positive-no coffee" estimate has stronger correlations with all rent values than the "flow positive" estimates. Both the flow and rent estimates are therefore comparable and interchangeable measures of landholders' opportunity costs at the study site.

\section{Opportunity cost heterogeneity}

To understand the factors determining the spatial distribution of high and low opportunity costs, flow net returns were assessed per landholder and land use. Significant correlations were found between landholder net returns $\mathrm{ha}^{-1}(\mathrm{n}=59)$ and number of plots used $(\mathrm{p}=0.412, \mathrm{p}<0.001)$, and number of land uses $(\mathrm{p}=0.459$, $\mathrm{p}<0.001)$. There was also a significant difference in opportunity costs between landholders without coffee (median $=0.00, \mathrm{n}=36$ ) and with coffee $($ median $=23,718.48, \mathrm{n}=23 ; \mathrm{U}=223, \mathrm{z}=-2.97$, $\mathrm{p}<0.001, \mathrm{r}=-0.39)$. Thus, high opportunity cost landholders were more likely to grow coffee, use more plots of land, and have more land uses.

The land-use regression models for coffee $((\mathrm{df}=6, \mathrm{n}=101)=$ $65.19, \mathrm{p}<0.001)$ explained between $48 \%-74 \%$ of the variance and correctly classified $92 \%$ of cases; crops $((\mathrm{df}=6, \mathrm{n}=101)=37.01$, $\mathrm{p}=0.00$ ) explained $31 \%-42 \%$ of the variance and correctly classified $75 \%$ of cases; and cattle $((\mathrm{df}=6, \mathrm{n}=101)=15.31, \mathrm{p}=$ 0.02 ) explained $14 \%-19 \%$ of the variance and correctly classified $67 \%$ of cases, were all statistically significant (Table 5). Four variables predicted the presence of coffee, particularly elevation and access; four variables predicted the presence of crops, particularly time to water; and two variables predicted the presence of cattle, particularly accessibility.

The land-use variables best predict the presence of coffee, followed by crops, and, to a lesser extent, cattle. There is a greater probability of finding coffee at lower elevations, in areas without access throughout the year, farther from the road, and closer to water. The presence of crops was more likely farther from water, at higher elevations, closer to the road, and on flat to medium sloped land. Cattle are more widespread throughout the study site, at different elevations, and on varied terrain, because they require less land specifications and because of the extensive availability of water. 
Table 4. Correlation (Spearman's $\rho$ ) between would rent, would sell, actual purchase price, flow, flow positive, and flow positive-no coffee estimates. $* * * \alpha=0.01, * * \alpha=0.05$.

\begin{tabular}{|c|c|c|c|c|c|c|c|}
\hline Spearman's & & Would rent & Would sell & $\begin{array}{l}\text { Actual purchase } \\
\text { price }\end{array}$ & Flow & Flow positive & $\begin{array}{c}\text { Flow positive-no } \\
\text { coffee }\end{array}$ \\
\hline \multirow[t]{2}{*}{ Would rent } & $\rho$ & 1.00 & $0.52^{* * *}$ & $0.51^{* * *}$ & 0.03 & $0.36^{* * *}$ & $0.39^{* * *}$ \\
\hline & $\mathrm{N}$ & 86 & 86 & 67 & 82 & 64 & 61 \\
\hline \multirow[t]{2}{*}{ Would sell } & $\rho$ & & 1.00 & $0.47^{* * *}$ & 0.07 & $0.39^{* * *}$ & $0.43^{* * *}$ \\
\hline & $\mathrm{N}$ & & 146 & 106 & 139 & 104 & 84 \\
\hline \multirow[t]{2}{*}{ Actual purchase price } & $\rho$ & & & 1.00 & -0.03 & $0.24^{* *}$ & $0.28^{* *}$ \\
\hline & $\mathrm{N}$ & & & 122 & 116 & 85 & 68 \\
\hline \multirow[t]{2}{*}{ Flow } & $\rho$ & & & & 1.00 & $1.00^{* * *}$ & $1.00^{* * *}$ \\
\hline & $\mathrm{N}$ & & & & 186 & 139 & 113 \\
\hline \multirow[t]{2}{*}{ Flow positive } & $\rho$ & & & & & 1.00 & $1.00^{* * *}$ \\
\hline & $\mathrm{N}$ & & & & & 139 & 113 \\
\hline
\end{tabular}

Table 5. Binary logistic regression predicting the likelihood of growing coffee, crops, and cattle rearing. Note: slope $0=$ flat, $1=$ medium, and $2=$ steep; ${ }^{* * *} \alpha=0.01,{ }^{* *} \alpha=0.05$, and ${ }^{*} \alpha=0.10$.

\begin{tabular}{|c|c|c|c|c|}
\hline Variable & $\beta$ & SE & Wald & $\begin{array}{l}\text { Odds } \\
\text { ratios }\end{array}$ \\
\hline \multicolumn{5}{|l|}{ Elevation: } \\
\hline Coffee & $-0.01 * * *$ & 0.01 & 6.88 & 0.99 \\
\hline Crops & $0.00 *$ & 0.00 & 3.24 & 1.00 \\
\hline Cattle & 0.00 & 0.00 & 0.29 & 1.00 \\
\hline \multicolumn{5}{|c|}{ Time to road: } \\
\hline Coffee & $0.02 *$ & 0.01 & 2.99 & 1.02 \\
\hline Crops & $-0.01 *$ & 0.01 & 2.89 & 0.99 \\
\hline Cattle & 0.00 & 0.01 & 0.41 & 1.00 \\
\hline \multicolumn{5}{|l|}{ Access (1): } \\
\hline Coffee & $-3.15 * * *$ & 1.03 & 9.33 & 0.04 \\
\hline Crops & 0.64 & 0.72 & 0.80 & 1.90 \\
\hline Cattle & $1.40 * *$ & 0.62 & 5.16 & 4.07 \\
\hline \multicolumn{5}{|l|}{ Slope (0): } \\
\hline Coffee & & & 0.22 & \\
\hline Crops & & & 2.84 & \\
\hline Cattle & & & 1.49 & \\
\hline \multicolumn{5}{|l|}{ Slope (1): } \\
\hline Coffee & 20.51 & $6,952.08$ & 0.00 & 0.00 \\
\hline Crops & -0.41 & 0.61 & 0.45 & 0.66 \\
\hline Cattle & -0.70 & 0.58 & 1.49 & 0.50 \\
\hline \multicolumn{5}{|l|}{ Slope (2): } \\
\hline Coffee & 20.97 & $6,952.08$ & 0.00 & 0.00 \\
\hline Crops & $-1.59 *$ & 0.95 & 2.81 & 0.21 \\
\hline Cattle & -0.54 & 0.74 & 0.53 & 0.58 \\
\hline \multicolumn{5}{|c|}{ Time to water: } \\
\hline Coffee & $-0.32 * *$ & 0.16 & 4.02 & 0.73 \\
\hline Crops & $0.09 * * *$ & 0.03 & 8.99 & 1.10 \\
\hline Cattle & $-0.06^{* *}$ & 0.03 & 5.09 & 0.94 \\
\hline \multicolumn{5}{|l|}{ Constant: } \\
\hline Coffee & 0.89 & $6,952.09$ & 0.00 & 2.45 \\
\hline Crops & $-4.97 * *$ & 2.56 & 3.76 & 0.02 \\
\hline Cattle & -1.99 & 2.32 & 0.74 & 0.14 \\
\hline
\end{tabular}

\section{DISCUSSION}

There is still much debate about the different approaches to opportunity cost estimation and their robustness (Corbera et al. 2007b, Wünscher 2008), as well as considerable challenges to identifying a reliable, accurate, and cost-effective method for determining opportunity costs of conservation (Wünscher et al., 2011). We estimated opportunity costs for water provision using the flow approach and the rent approach in a multiland-use farming system. We found that the two methods offered broadly comparable and consistent opportunity cost values although each had strengths and weaknesses that need to inform their use.

Quantifying and understanding the heterogeneity of opportunity costs is an essential first step in developing a cost effective PES scheme (Tallis and Polasky 2009, Adams et al. 2010, Badola et al. 2010). In this research, the different landholder, land, and landuse characteristics clearly determined the spatial distribution of opportunity costs. We discuss how our results demonstrate that discriminating payments across a range of heterogeneous factors is key to PES scheme design.

\section{Opportunity cost estimation}

We estimated opportunity costs as a means of assessing the cost of improving drinking-water quality by taking land out of production. The mean flow net returns for all land uses at the catchment is US\$1410 ha ${ }^{-1}$ and the median is US\$145 ha ${ }^{-1}$. The mean estimate is high, at the upper margin of results of other studies. For instance, Fisher et al. (2011b) found a mean of US\$1188 from government census data for Tanzanian agriculture. Naidoo and Adamowicz (2006) reported net benefits of US\$770 for smallholder agriculture and US\$1124 for cattle ranching at the Mbaracayu Biosphere Reserve in Paraguay based on secondary sources. The median flow estimate represents a more stable and long-term figure for the study site. This estimate is also in line with the opportunity costs (ranging between US\$39 and US\$509) reported for similar land-use types (Cacho et al. 2005, Chomitz et al. 2005, Börner and Wunder 2008, Wünscher et al. 2008, Bottcher et al. 2009).

Regarding individual land uses, the mean opportunity cost of US\$5710 for coffee is high but within the range of previous studies (US\$2247-US\$12,750 ha-1) of other high-value crops, such as oil, palm, and soybean (Naidoo and Adamowicz 2006, Bottcher et al. 2009, Börner et al. 2010, Fisher et al. 2011a). Coffee is the main local and national agro-export (IHCAFE 2012) and at the time of the study was being bought at the highest price for a decade (Nasdaq 2014). Vegetable crops can yield high net returns as well, but are riskier because of high transaction costs associated with market variability, access, and substantial upfront investments 
(Blandon et al. 2009, Hellin et al. 2009). On the other hand, cattle ranching and forest product collection, which are primarily undertaken for subsistence or for local markets at the study site, yield substantially lower net returns.

Temporal and spatial market feedbacks affect the distribution of farmer returns (Wells 1992, Chan et al. 2007, Tallis and Polasky 2009). In the study year, coffee prices were high but prices were low for cattle and crops. Because these values change over time, availability of data on these long-term feedbacks and spatial heterogeneity should be considered in future research. Nonetheless, the substantial difference between overall and individual land-use opportunity costs confirms the need to consider each land use and its associated land and landholder characteristics separately to understand spatial and social heterogeneity (Adams et al. 2010).

\section{The flow and rent opportunity cost approaches}

We applied the flow and rent approaches to understand their accuracy and reliability. The flow approach is the most widely used approach because it provides detailed information on local heterogeneity of farmers' net returns. However, it requires several assumptions (e.g., value of labor), costly and time-consuming data collection, accounting for short-term variability of returns, and knowledge of the local context. The rent approach is considered less reliable and dependent on the existence of a market for land (Grieg-Gran 2008). However, the rent approach is cost-effective, can be based on self-reported land values, and only requires adjustment of land values to the study year.

Despite the difference in data requirements, both approaches provided broadly comparable and consistent estimates. The flow approach is appropriate when detailed information on the heterogeneity of opportunity costs is a key factor for designing conservation strategies. This is particularly the case for watershed services: understanding the distribution of costs and benefits throughout the catchment (not just upstream-downstream) is important for determining viable payment schemes. Although the rent approach does not provide heterogeneity information, it does help deal with the volatility of the flow estimates, it provides unit area values, it is useful when resources are limited, and for triangulating the results obtained by more complex approaches.

\section{Opportunity cost heterogeneity: implications for payment for ecosystem services (PES) scheme contracting}

To design efficient PES schemes, we need to understand the enablers and challenges for providers to enter into potential contracts (Michael 2003, Knight et al. 2011, Raymond and Brown 2011). Efficient schemes ensure that compensation for upstream landholders is at least equal to the opportunity costs of their land use. However, it is important to acknowledge that in some cases landholders will accept less than their full opportunity costs for reasons such as to bring themselves into compliance with social codes for land use, to secure land tenure, or because of the high levels of competition in supply (Kosoy and Corbera 2010, Muradian et al. 2010). The payment must also remain smaller than the economic value of any environmental externalities (Kosoy et al. 2007). However, exactly how compensation should be distributed among providers is a fundamental challenge for PES scheme design, particularly at the research site because AESMO and the German corporation GIZ have been studying the possibility of developing a water PES scheme at the site.
Each upstream hectare cannot be assumed to have the same opportunity cost and capacity to provide ecosystem services because of their differing location in relation to water sources, land use, and landholder and land characteristics. Scheme payments can be based on the most profitable land use, or they can be discriminately aligned to each land use (Pirard 2008). In our case, using the highest opportunity cost at the study site would make payments prohibitively expensive. For instance, average opportunity costs for 1 ha of coffee are equivalent to 4 ha of crops or 20 ha of cattle ranching. Thus, discriminate payments are a better option, and they have been found to be substantially more cost-effective and equitable, allowing for the conservation of more land and spreading resources across a greater number of providers (Börner et al. 2010). However, even the discrimination approach can be financially and practically unfeasible when high opportunity costs are present.

Balmford and Whitten (2003) highlight the importance of understanding how much land can be removed from production while still allowing maintenance and growth of income. Although water quality testing was not carried out, the land-use survey showed that each land use has a different environmental impact (another heterogeneity factor). Forest product collection has a negligible impact on water quality and low economic value. Coffee and vegetables cover a small proportion of land (less than $10 \%$ ) and are of high economic value. Vegetables are the only intensively managed crop, which receives high agrochemical applications, making it the highest environmental impact land use compounded by its location at high altitudes. Coffee receives a lower amount of agrochemicals so it has a lesser environmental impact compared to vegetable crops. Cattle ranching is extensive on often steep slopes, but without the need for planting improved grass, so it is likely to be the second land use that most affects water quality because of direct access to streams/rivers (e.g., Conroy et al. 2016). Thus, conservation for water quality should target vegetable crops in the core zone and cattle ranching and already forested areas throughout the catchment. However, it is important to note that cattle ranching is a subsistence and commercial activity, so its inclusion in a PES scheme would need to consider its effect on local livelihood strategies (Plumb et al. 2012).

The small but profitable coffee plots tend to be located in remote and inaccessible areas and at lower elevations than other land uses. In contrast, Wünscher et al. (2011) suggested that crops with all year accessibility, with good road conditions, and low transportation costs have higher returns. Studies that use factors such as accessibility as a proxy for land value, and therefore opportunity costs, suggest the same relationship (e.g., Jacoby 2000, Naidoo and Adamowicz 2006, Börner and Wunder 2008). These arguments are likely to be true within one land use but are less applicable for differences in land values across multiple land uses. In any case, coffee is the highest value crop typically grown in remote areas of the buffer zone of the reserve, which would be hard to monitor in a PES scheme. All this suggests that coffee is best managed in a different way from other land uses, such as shade coffee, and still provide ecosystem services. If coffee were excluded from contracting, total opportunity costs would fall to less than a fourth of the initial estimate. So ideally PES schemes would be better aimed at high environmental impact land uses of low to mid returns, with payments providing sufficient incentive for changing or discontinuing them. 
Water services are considered to provide directional benefits, from upstream providers to downstream beneficiaries (Fisher et al. 2009). However, most providers of the service reside throughout the catchment (not necessarily at their plots) making them also beneficiaries of the service; this has rarely been mentioned in the literature. This duality of roles is potentially important for contracting in PES schemes, requiring further research, because it can influence providers' willingness to enter into contracts. Identifying and targeting landholders with dual roles could be a good starting point for a PES scheme. Such targeting could save time, help personalize environmental awareness efforts, and, if managed appropriately, could be crucial to secure the acceptance of the scheme. The challenges of securing unused land and the dual role of most landholders emphasize the need for a scheme that completely sets land aside because of the challenges of regulating and monitoring land (non) use.

As long as there is substantial heterogeneity in opportunity costs of supplying ecosystem services, hidden information between buyers and suppliers of services will be a problem. Society will benefit more if scheme payments only compensate landowners' opportunity costs, and no more. There are several methods that target or discriminate PES scheme contracts, such as spatial targeting (Wendland et al. 2010, Wònscher et al. 2008), costeffective targeting based on a cost-benefit ratio (Chen et al. 2010), targeting specific groups such as the poor (Gauvin et al. 2010, Kaczan et al. 2013), conservation targets (Schroter et al. 2014), and the more recent procurement PES auctions (Ferraro 2008). These options could all be used at the research site to account for opportunity cost heterogeneity and guide scheme design.

\section{CONCLUSIONS}

Determining landholders' opportunity costs is key to defining fair and targeted payments in schemes, such as PES, when financial resources are often limited. However, estimating opportunity costs is complex, and there is still much debate about the different estimation methods, their robustness, and the factors explaining their distribution. We compared the flow and rent approaches to opportunity cost estimation and found them to be broadly comparable and consistent. The flow approach helps to understand the heterogeneity of opportunity costs, which is needed to inform payment distribution and the design of a viable PES scheme. The rent approach helps deal with the volatility of the flow estimates, provides unit area values, and is useful when resources are limited.

We found that in settings characterized by complex land-use patterns and heterogeneous opportunity costs, uniform payments will likely result in low participation hence discriminate payments are required. In our case, this means discriminating payments to providers in terms of a range of factors is key to PES scheme design. These factors include the spatial heterogeneity between upstream and downstream plots, core and buffer zones, and distance of land from water sources, as well as how opportunity costs vary depending on land-use differences (e.g., environmental impact) and landholder characteristics (e.g., dual landholders that are both provider and beneficiary). The results indicate that targeting dual landholders with low opportunity costs and high impacts, as well as ensuring the protection of unused land through specific governance structures, are key to a viable scheme in the research site.
Responses to this article can be read online at: http://www.ecologyandsociety.org/issues/responses. $\mathrm{php} / 8787$

\section{Acknowledgments:}

Rendón was funded by the University of Leeds Fully-funded International Research Scholarship. This work was carried out with the aid of a grant from the Latin American and Caribbean Environmental Economist Program (LACEEP). We thank the AESMO (Asociación Ecológica San Marcos de Ocotepeque) and local research assistants for their support, and the invaluable participation of all residents and farmers at the study site.

\section{LITERATURE CITED}

Adams, V. M., R. L. Pressey, and R. Naidoo. 2010. Opportunity costs: who really pays for conservation? Biological Conservation 143(2):439-448. http://dx.doi.org/10.1016/j.biocon.2009.11.011

Agulla Menoni, J. 2012. Consultoria internacional: misión de contribución a la precisión de los indicadores de un programa de apoyo de la UE al Sector Forestal en Honduras. Deutsche Gesellschaft für Internationale Zusammenarbeit (GIZ), Bonn, Germany. [online] URL: http://mosef.org.hn/wp-content/ uploads/2015/11/jorge agulla 3.pdf

Asociacion Ecologica San Marcos de Ocotepeque (AESMO). 2010. Inventario, tipificacion y valorizacion de bienes y servicios ambientales, reserva biologica güisayote. Asociacion Ecologica San Marcos de Ocotepeque, San Marcos de Ocotepeque, Honduras.

Asquith, N. M., M. T. Vargas, and S. Wunder. 2008. Selling two environmental services: in-kind payments for bird habitat and watershed protection in Los Negros, Bolivia. Ecological Economics 65:675-684. http://dx.doi.org/10.1016/j.ecolecon.2007.12.014

Aylward, B. 2005. Land use, hydrological function and economic valuation. Pages 99-120 in M. Bonell and L. A. Bruijnzeel, editors. Forests, water and people in the humid tropics: past, present and future hydrological research for integrated land and water management. Cambridge University Press, Cambridge, UK. http://dx.doi.org/10.1017/CBO9780511535666.012

Badola, R., S. A. Hussain, B. K. Mishra, B. Konthoujam, S. Thapliyal, and P. M. Dhakate. 2010. An assessment of ecosystem services of Corbett Tiger Reserve, India. Environmentalist 30 (4):320-329. http://dx.doi.org/10.1007/s10669-010-9278-5

Balmford, A., and T. Whitten. 2003. Who should pay for tropical conservation, and how could the costs be met? Oryx 37 (2):238-250. http://dx.doi.org/10.1017/S0030605303000413

Banco Central de Honduras (BCH). 2011. Memoria anual 2011. Memoria Anual. Banco Central de Honduras, Tegucigalpa, Honduras. [online] URL: http://www.bch.hn/memoria anual. php

Blandon, J., S. Henson, and J. Cranfield. 2009. Small-scale farmer participation in new agri-food supply chains: case of the supermarket supply chain for fruit and vegetables in Honduras. Journal of International Development 21(7):971-984. http://dx. doi.org/10.1002/jid.1490 
Börner, J., and S. Wunder. 2008. Paying for avoided deforestation in the Brazilian amazon: from cost assessment to scheme design. International Forestry Review 10(3):496-511. http://dx.doi. org/10.1505/ifor.10.3.496

Börner, J., S. Wunder, S. Wertz-Kanounnikoff, M. R. Tito, L. Pereira, and N. Nascimento. 2010. Direct conservation payments in the Brazilian Amazon: scope and equity implications. Ecological Economics 69(6):1272-1282. http://dx.doi.org/10.1016/ j.ecolecon.2009.11.003

Borrego, A., and M. Skutsch. 2014. Estimating the opportunity costs of activities that cause degradation in tropical dry forest: implications for REDD+. Ecological Economics 101:1-9. http:// dx.doi.org/10.1016/j.ecolecon.2014.02.005

Böttcher, H., K. Eisbrenner, S. Fritz, G. Kindermann, F. Kraxner, I. McCallum, and M. Obersteiner. 2009. An assessment of monitoring requirements and costs of 'reduced emissions from deforestation and degradation'. Carbon Balance and Management 4:7. http://dx.doi.org/10.1186/1750-0680-4-7

Bruijnzeel, L. A. 2004. Hydrological functions of tropical forests: not seeing the soil for the trees? Agriculture, Ecosystems and Environment 104:185-228. http://dx.doi.org/10.1016/j.agee.2004.01.015

Bruijnzeel, S., and M. V. Noordwijk. 2008. Deforestation and the multiple functions of tropical watersheds: are tropical forests indispensable for regulating rainfall and ensuring clean and reliable water supplies? ASB policy briefs 08. ASB Partnerships for the Tropical Forest Margins, Nairobi, Kenya.

Bryan, B. A. 2013. Incentives, land use, and ecosystem services: synthesizing complex linkages. Environmental Science and Policy 27:124-134. http://dx.doi.org/10.1016/j.envsci.2012.12.010

Cacho, O. J., G. R. Marshall, and M. Milne. 2005. Transaction and abatement costs of carbon-sink projects in developing countries. Environment and Development Economics 10 (05):597-614. http://dx.doi.org/10.1017/s1355770x05002056

Cattaneo, A. 2002. Balancing agricultural development and deforestation in the Brazilian amazon. International Food Policy Research Institute, Washington, D.C., USA. [online] URL: http:// ebrary.ifpri.org/cdm/ref/collection/p15738coll2/id/48037

Cavailhès, J., and P. Wavresky. 2003. Urban influences on periurban farmland prices. European Review of Agricultural Economics 30(3):333-357. http://dx.doi.org/10.1093/erae/30.3.333

Chan, K. M. A., R. M. Pringle, J. Ranganathan, C. L. Boggs, Y. L. Chan, P. R. Ehrlich, P. K. Haff, N. E. Heller, K. Al-Krafaji, and D. P. Macmynowski. 2007. When agendas collide: human welfare and biological conservation. Conservation Biology 21 (1):59-68. http://dx.doi.org/10.1111/j.1523-1739.2006.00570.x

Charvériat, C. 2001. Bitter coffee: how the poor are paying for the slump in coffee prices. Oxfam, Oxford, UK. [online] URL: http:// policy-practice.oxfam.org.uk/publications/bitter-coffee-how-thepoor-are-paying-for-the-slump-in-coffee-prices-114002

Chen, X., F. Lupi, A. Viða, G. He, and J. Liu. 2010. Using costeffective targeting to enhance the efficiency of conservation investments in payments for ecosystem services. Conservation Biology 24:1469-1478. http://dx.doi.org/10.1111/j.1523-1739.2010.01551.
Chomitz, K. M., K. Alger, T. S. Thomas, H. Orlando, and P. V. Nova. 2005. Opportunity costs of conservation in a biodiversity hotspot: the case of Southern Bahia. Environment and Development Economics 10:293-312. http://dx.doi.org/10.1017/ $\underline{\mathrm{S} 1355770 \mathrm{X} 05002081}$

Claassen, R., A. Cattaneo, and R. Johansson. 2008. Cost-effective design of agri-environmental payment programs: U.S. experience in theory and practice. Ecological Economics 65:737-752. http:// dx.doi.org/10.1016/j.ecolecon.2007.07.032

Corbera, E., K. Brown, and W. N. Adger. 2007a. The equity and legitimacy of markets for ecosystem services. Development and Change 38(4):587-613. http://dx.doi.org/10.1111/j.1467-7660.2007.00425. $\underline{\mathrm{x}}$

Corbera, E., N. Kosoy, and M. M. Tuna. 2007b. Equity implications of marketing ecosystem services in protected areas and rural communities: case studies from Meso-America. Global Environmental Change 17(3-4):365-380. http://dx.doi.org/10.1016/ j.gloenvcha.2006.12.005

Curran, M., B. Kiteme, T. Wünscher, T. Koellner, and S. Hellweg. 2016. Pay the farmer, or buy the land?-Cost-effectiveness of payments for ecosystem services versus land purchases or easements in Central Kenya. Ecological Economics 127:59-67. http://dx.doi.org/10.1016/j.ecolecon.2016.03.016

Dong, Z., Y. Yan, J. Duan, X. Fu, Q. Zhou, X. Huang, X. Zhu, and J. Zhao. 2011. Computing payment for ecosystem services in watersheds: an analysis of the middle route project of south-tonorth water diversion in China. Journal of Environmental Sciences 23(12):2005-2012. http://dx.doi.org/10.1016/s1001-0742(10)60663-8

Ericksen, P. J., K. McSweeney, and F. W. Madison. 2002. Assessing linkages and sustainable land management for hillside agroecosystems in central Honduras: analysis of intermediate and catchment scale indicators. Agriculture Ecosystems and Environment 91:295-311. http://dx.doi.org/10.1016/S0167-8809 (01)00224-9

Escuela Nacional de Ciencias Forestales (ESNACIFOR) and U. S. Agency for International Development (USAID). 2002. Diagnóstico general de las cuencas hidrográficas del municipio de San Marcos, Ocotepeque - Proyecto de Desarrollo Forestal. Municipalidad San Marcos de Ocotepeque, Ocotepeque, Honduras.

Fauna and Flora International (FFI). 2014. Opportunity cost analysis: Lessons learned from REDD+ and other conservation strategies. Fauna and Flora International, Cambridge, UK. [online] URL: http://www.fauna-flora.org/wp-content/uploads/ Opportunity-Cost-Analysis1.pdf

Ferraro, P. J. 2004. Direct payments to protect endangered ecosystems and experimental methods to estimate payment costs. EEPSEA Special and Technical Paper. Economy and Environment Program for Southeast Asia, Laguna, Philippines.

Ferraro, P. J. 2008. Asymmetric information and contract design for payments for environmental services. Ecological Economics 65 (4):810-821. http://dx.doi.org/10.1016/j.ecolecon.2007.07.029

Fisher, B., D. P. Edwards, X. Giam, and D. S. Wilcove. 2011a. The high costs of conserving Southeast Asia's lowland rainforests. 
Frontiers in Ecology and the Environment 9(6):329-334. http://dx. doi.org/10.1890/100079

Fisher, B., S. L. Lewis, N. D. Burgess, R. E. Malimbwi, P. K. Munishi, R. D. Swetnam, R. K. Turner, S. Willcock, and A. Balmford. 2011 b. Implementation and opportunity costs of reducing deforestation and forest degradation in Tanzania. Nature Climate Change 1(3):161-164. http://dx.doi.org/10.1038/ $\underline{\text { nclimate } 1119}$

Fisher, B., R. K. Turner, and P. Morling. 2009. Defining and classifying ecosystem services for decision making. Ecological Economics 68(3):643-653. http://dx.doi.org/10.1016/j. ecolecon.2008.09.014

Food and Agriculture Organization (FAO). 2010. Evaluación de los recursos forestales mundiales 2010: informe principal. Food and Agriculture Organization, Rome, Italy. [online] URL: http://www. fao.org/docrep/013/i1757s/i1757s00.htm

Gareau, B. J. 2007. Ecological values amid local interests: natural resource conservation, social differentiation, and human survival in Honduras. Rural Sociology 72:244-268.

Gauvin, C., E. Uchida, S. Rozelle, J. Xu, and J. Zhan. 2010. Costeffectiveness of payments for ecosystem services with dual goals of environment and poverty alleviation. Environmental Management 45:488-501. http://dx.doi.org/10.1007/s00267-009-9321-9

Global Water Partnership-Centroamerica. 2011. Situacion de los recursos hidricos en centroamerica: hacia una gestion integrada. GWP-Centroamerica, Tegucigalpa, Honduras. [online] URL: http://www.gwp.org/global/gwp-cam files/situaciondelosrecursoshidricos. pdf

Goodwin, B. K., A. K. Mishra, and F. Ortalo-Magná. 2003. What's wrong with our models of agricultural land values? American Journal of Agricultural Economics 85:744-752. http:// dx.doi.org/10.1526/003601107781169992

Grieg-Gran, M. 2008. The cost of avoiding deforestation: update of the report prepared for the stern review of the economics of climate change. London: International Institute for Environment and Development, London, UK. [online] URL: http://pubs.iied. org/G02489/

Gwartney, T. 1999. Land rent compared with market value. Henry George Institute, New York, New York, USA. [online] URL: http://www.henrygeorge.org/ted.htm

Hellin, J., M. Lundy, and M. Meijer. 2009. Farmer organization, collective action and market access in meso-america. Food Policy 34(1):16-22. http://dx.doi.org/10.1016/j.foodpol.2008.10.003

Hunt, C. 2010. Compensating for the costs of reducing deforestation in Papua New Guinea. Pacific Economic Bulletin 25 (3):64-88.

Instituto de Conservación Forestal (ICF). 1987. Decreto No. 87-87 declaratoria bosques nublados, 5th of August 1987. La Gaceta, Tegucigalpa, Honduras. [online] URL: http://icf.gob.hn/ wp-content/uploads/2015/09/AP-Decreto-87-87-Declaratoria-Bosques$\underline{\text { Nublados.pdf }}$

Instituto Hondureño del Cafe (IHCAFE). 2012. Informe anual: cosecha 2010-2011. Instituto Hondureño del Cafe, Tegucigalpa, Honduras.
Instituto Nacional de Estadistica (INE). 2014. Datos y estadistica. Instituto Nacional de Estadistica, Tegucigalpa, Honduras. [online] URL: http://www.ine.gob.hn

Jack, B. K., B. Leimona, and P. J. Ferraro. 2009. A revealed preference approach to estimating supply curves for ecosystem services: use of auctions to set payments for soil erosion control in Indonesia. Conservation Biology 23(2):359-367. http://dx.doi. org/10.1111/j.1523-1739.2008.01086.x

Jacoby, H. G. 2000. Access to markets and the benefits of rural roads. Economic Journal 110(465):713-737. http://dx.doi. org/10.1111/1468-0297.00562

Jansen, H. G. P., J. Pender, A. Damon, W. Wielemaker, and R. Schipper. 2006. Policies for sustainable development in the hillside areas of Honduras: a quantitative livelihoods approach. Agricultural Economics 34:141-153. http://dx.doi.org/10.1111/ j.1574-0864.2006.00114.X

Jouravlev, A. 2004. Drinking water supply and sanitation services on the threshold of the XXI century. Recursos naturales e infraestructura. CEPAL-United Nations, Santiago, Chile. [online] URL: http://repositorio.cepal.org/handle/11362/6454

Kaczan, D., B. M. Swallow, and W. L. (Vic) Adamowicz. 2013. Designing a payments for ecosystem services (PES) program to reduce deforestation in Tanzania: an assessment of payment approaches. Ecological Economics 95:20-30. http://dx.doi. org/10.1016/j.ecolecon.2013.07.011

Knight, A. T., H. S. Grantham, R. J. Smith, G. K. McGregor, H. P. Possingham, and R. M. Cowling. 2011. Land managers' willingness-to-sell defines conservation opportunity for protected area expansion. Biological Conservation 144(11):2623-2630. http://dx.doi.org/10.1016/j.biocon.2011.07.013

Kosoy, N., and E. Corbera. 2010. Payments for ecosystem services as commodity fetishism. Ecological Economics 69:1228-1236. http://dx.doi.org/10.1016/j.ecolecon.2009.11.002

Kosoy, N., M. Martinez-Tuna, R. Muradian, and J. MartinezAlier. 2007. Payments for environmental services in watersheds: insights from a comparative study of three cases in central america. Ecological Economics 61(2-3):446-455. http://dx.doi. org/10.1016/j.ecolecon.2006.03.016

Larson, A. M., P. Pacheco, F. Toni, and M. Vallejo. 2007. Trends in Latin American forestry decentralisations: legal frameworks, municipal governments and forest dependent groups. International Forestry Review 9:734-747. http://dx.doi.org/ $\underline{10.1505 / \text { ifor. } 9.3 .734}$

Martin, T. E., and G. A. Blackburn. 2009. The effectiveness of a Mesoamerican 'paper park in conserving cloud forest avifauna. Biodiversity Conservation 18:3841-3859. http://dx.doi.org/10.1007/ s10531-009-9683-6

Michael, J. A. 2003. Efficient habitat protection with diverse landowners and fragmented landscapes. Environmental Science and Policy 6(3):243-251. http://dx.doi.org/10.1016/s1462-9011 (03)00042-X

Mohan, S. 2007. Market-based price-risk management for coffee producers. Development Policy Review 25(3):333-354. http://dx. doi.org/10.1111/j.1467-7679.2007.00373.x 
Muradian, R., E. Corbera, U. Pascual, N. Kosoy, and P.H. May. 2010. Reconciling theory and practice: an alternative conceptual framework for understanding payments for environmental services. Ecological Economics 69:1202-1208. http://dx.doi. org/10.1016/j.ecolecon.2009.11.006

Naidoo, R., and W. L. Adamowicz. 2006. Modeling opportunity costs of conservation in transitional landscapes. Conservation Biology 20(2):490-500. http://dx.doi.org/10.1111/j.1523-1739.2006.00304. $\underline{\mathrm{x}}$

Naidoo, R., A. Balmford, P. J. Ferraro, S. Polasky, T. H. Ricketts, and M. Rouget. 2006. Integrating economic costs into conservation planning. Trends in Ecology and Evolution 21 (12):681-687. http://dx.doi.org/10.1016/j.tree.2006.10.003

Nasdaq. 2014. Latest price and chart for coffee. Nasdaq, New York, New York, USA. [online]. URL: http://www.nasdaq.com/ markets/coffee.aspx?timeframe $=10 \mathrm{y}$.

Olmstead, S. M. 2010. The economics of water quality. Review of Environmental Economics and Policy 4(1):44-62. http://dx.doi. org/10.1093/reep/rep016

Pagiola, S. 2008. Payments for environmental services in Costa Rica. Ecological Economics 65:712-724. http://dx.doi.org/10.1016/ j.ecolecon.2007.07.033

Pagiola, S., A. Arcenas, and G. Platais. 2005. Can payments for environmental services help reduce poverty? An exploration of the issues and the evidence to date from Latin America. World Development 33(2):237-253. http://dx.doi.org/10.1016/j. worlddev.2004.07.011

Pagiola, S., and B. Bosquet 2009. Estimating the costs of REDD at the country level. World Bank, Washington, D.C., USA. [online] URL: http://www.forestcarbonpartnership.org/sites/ forestcarbonpartnership.org/files/REDD-Econ 04-09-09.pdf

Munich Personal RePEc Archive MPRA (18062): 23. WHAT IS THIS?

Pagiola, S., and G. Platais. 2002. Payments for environmental services. Environment strategy notes no. 3. World Bank Environment Department, Washington, D.C., USA. [online] URL: http://siteresources.worldbank.org/INTEEI/Resources/ EnvStrategyNote32002.pdf

Pirard, R. 2008. Estimating opportunity costs of avoided deforestation (REDD): application of a flexible stepwise approach to the Indonesian pulp sector. International Forestry Review 10(3):512-522. http://dx.doi.org/10.1505/ifor.10.3.512

Plumb, S. T., E. A. Nielsen, and Y.-S. Kim. 2012. Challenges of opportunity cost analysis in planning REDD+: a Honduran case study of social and cultural values associated with indigenous forest uses. Forests 3(2):244-264. http://dx.doi.org/10.3390/ $\underline{\mathrm{f} 3020244}$

Postel, S. L., and B. H. Thompson. 2005. Watershed protection: capturing the benefits of nature's water supply services. Natural Resources Forum 29(2):98-108. http://dx.doi.org/10.1111/ j.1477-8947.2005.00119.x

Rangel Soares, L. C., M. O. Griesinger, J. N. W. Dachs, M. A. Bittner, and S. Tavares. 2002. Inequities in access to and use of drinking water services in Latin America and the Caribbean. Revista Panamericana de Salud Publica = Pan American journal of public health 11(5-6):386-96.

Raymond, C. M., and G. Brown. 2011. Assessing conservation opportunity on private land: socio-economic, behavioral, and spatial dimensions. Journal of Environmental Management 92 (10):2513-2523. http://dx.doi.org/10.1016/j.jenvman.2011.05.015

Rivera, S., P. Martinez de Anguita, R. D. Ramsey, and T. A. Crowl. 2013. Spatial modeling of tropical deforestation using socioeconomic and biophysical data. Small-scale Forestry 12 (2):321-334. http://dx.doi.org/10.1007/s11842-012-9214-2

Rosa, H., S. Kandel, and L. Dimas. 2003. Compensation for environmental services and rural communities. PRISMA, San Salvador, El Salvador. [online] URL: https://www.cbd.int/doc/ case-studies/inc/cs-inc-prisma-en-01.pdf

Schröter, M., G. M. Rusch, D. N. Barton, S. Blumentrath, and B. Nordén. 2014. Ecosystem services and opportunity costs shift spatial priorities for conserving forest biodiversity. PLOS ONE 9 (11):e112557. http://dx.doi.org/10.1371/journal.pone.0112557

Scott, D. F., L. A. Bruijnzeel, and J. Mackensen. 2005. The hydrological and soil impacts of forestation in the tropics. Pages 622-651 in M. Bonell and L. A. Bruijnzeel, editors. Forests, water and people in the humid tropics: past, present and future hydrological research for integrated land and water management. International Hydrology Series. Cambridge University Press, Cambridge, UK. http://dx.doi.org/10.1017/cbo9780511535666.032

Secretaria de Recursos Naturales y Ambiente (SRNA). 1997. Acuerdo presidencial No. 921-97 reglamento de Aareas protegidas SINAPH, 30th of June 1997. La Gaceta, Tegucigalpa, Honduras. [online] URL: http://www.iadb.org/research/legislacionindigena/ leyn/docs/HON-Acuerdo-Presidencial-921-97-Reglamento-AreasProtegidas SINAPH.pdf

Siikamaki, J., and D. F. Layton. 2007. Potential cost-effectiveness of incentive payment programs for the protection of nonindustrial private forests. Land Economics 83:539-560. http://dx. doi.org/10.3368/le.83.4.539

Sinden, J. A. 2004. Estimating the opportunity costs of biodiversity protection in the Brigalow Belt, New South Wales. Journal of Environmental Management 70(4):351-362. http://dx. doi.org/10.1016/j.jenvman.2003.12.013

Smith, L., A. Inman, and R. Cherrington. 2012. The potential of land conservation agreements for protection of water resources. Environmental Science and Policy 24:92-100. http://dx.doi. org/10.1016/j.envsci.2012.07.017

Smith, L. D., and K. Porter. 2010. Management of catchments for the protection of water resources: drawing on the New York City watershed experience. Regional Environmental Change 10 (4):311-326. http://dx.doi.org/10.1007/s10113-009-0102-z

Southworth, J., H. Nagendra, L. A. Carlson, and C. Tucker. 2004. Assessing the impact of Celaque National Park on forest fragmentation in western Honduras. Applied Geography 24:303-322. http://dx.doi.org/10.1016/j.apgeog.2004.07.003

Tallis, H., and S. Polasky. 2009. Mapping and valuing ecosystem services as an approach for conservation and natural-resource 
management. Pages 265-283 in R. S. Ostfeld and W. H. Schlesinger, editors. The Year in Ecology and Conservation Biology 2009. New York Academy of Sciences, New York, New York, USA. http://dx.doi.org/10.1111/j.1749-6632.2009.04152.x

Tóth, S. F., G. J. Ettl, and S. S. Rabotyagov. 2010. Ecosel: an auction mechanism for forest ecosystem services. Mathematical and Computational Forestry and Natural Resource Sciences 2 (2):99-116. [online] URL: http://mcfns.com/index.php/Journal/ article/view/MCFNS.2-99/MCFNS-2\%3A99

Trevett, A. F., R. C. Carter, and S. F. Tyrrel. 2004. Water quality deterioration: a study of household drinking water quality in rural Honduras. International Journal of Environmental Health Research 14(4):273-283. http://dx.doi.org/10.1080/09603120410001725612

UNICEF and World Health Organization (WHO). 2012. Progress on drinking water and sanitation: 2012 update. UNICEF, New York, New York, USA. [online] URL: http://www.unicef. org/french/media/files/JMPreport2012.pdf

Weersink, A., S. Clark, C. G. Turvey, and R. Sarker. 1999. The effect of agricultural policy on farmland values. Land Economics 75(3):425-439. http://dx.doi.org/10.2307/3147188

Wells, M. 1992. Biodiversity conservation, affluence and poverty - mismatched costs and benefits and efforts to remedy them. Ambio 21(3):237-243.

Wendland, K. J., M. Honzák, R. Portela, B. Vitale, S. Rubinoff, and J. Randrianarisoa. 2010. Targeting and implementing payments for ecosystem services: opportunities for bundling biodiversity conservation with carbon and water services in Madagascar. Ecological Economics 69:2093-2107. http://dx.doi. org/10.1016/j.ecolecon.2009.01.002

Wunder, S. 2005. Payments for environmental services: some nuts and bolts. CIFOR occasional paper. Center for International Forestry Research, Bogor Barat, Indonesia. [online] URL: http:// www.cifor.org/publications/pdf files/OccPapers/OP-42.pdf

Wünscher, T. 2008. Spatial targeting of payments for environmental services in Costa Rica: a site selection tool for increasing conservation benefits. Dissertation. Rheinischen Friedrich-Wilhelm-Universität, Bonn, Germany.

Wünscher, T., S. Engel, and S. Wunder. 2008. Spatial targeting of payments for environmental services: a tool for boosting conservation benefits. Ecological Economics 65(4):822-833. http://dx.doi.org/10.1016/j.ecolecon.2007.11.014

Wünscher, T., S. Engel, and S. Wunder. 2011. Practical alternatives to estimate opportunity costs of forest conservation. EAAE 2011 congress change and uncertainty - challenges for agriculture, food and natural resources. European Association of Agricultural Economists, Zurich, Switzerland. [online] URL: http:// ageconsearch.umn.edu/handle/115774 
Appendix 1. Socioeconomic and farmer characteristics for opportunity cost survey respondents $(n=62)$. Note: ${ }^{1}$ forest use is not included here; ${ }^{2}$ one observation was removed as the respondent had a university degree in agronomy.

\begin{tabular}{lcccc}
\hline Variable & $\begin{array}{c}\text { Mean/ } \\
\text { Proportion }\end{array}$ & SE & SD & Range \\
\hline Age & 56 & 1.62 & 12.76 & $27-89$ \\
Female & 0.11 & 0.04 & 0.32 & \\
Years living in area & 54.44 & 1.79 & 14.13 & $25-89$ \\
Years of education & 4.23 & 0.63 & 4.93 & $0-18$ \\
Family size & 5.35 & 0.35 & 2.74 & $1-12$ \\
Productive land uses per farmer ${ }^{1}$ & 1.45 & 0.12 & 0.95 & $0-4$ \\
Days of agronomic training received & 34.73 & 12.04 & 94.79 & $0-481$ \\
Household income sources & 2.53 & 0.22 & 1.71 & $0-7$ \\
Income contributed by landholder & 74.80 & 4.34 & 34.21 & $0-100$ \\
Years owning land plots $_{\text {Plots per farmer }}^{17.78}$ & 1.44 & 11.32 & $0.5-50$ \\
& 1.13 & 0.07 & 0.58 & $1-4$ \\
\hline
\end{tabular}

